\title{
"The New Americans": The Creation of a Typology of Vietnamese-American Identity in Children's Literature
}

\author{
SUBARNO CHATTARJI
}

The influx of Vietnamese refugees, "boat people," and immigrants into the United States after April 1975 has led to the establishment of a significant Vietnamese-American community. There is a body of literature written for children and young adults that creates and delineates this new community within the topography of a welcoming and immigrant-friendly USA. This paper will examine the meanings and implications of the appellation "VietnameseAmerican" as defined within a body of nonfiction children's literature. It will highlight how these texts negotiate questions related to refugee status, immigration, identity and belonging, contributing in many instances to a bland re-creation of a formerly oppressed but now coherent and increasingly prosperous and Americanized people. The children's literature plays an important role in defining the relatively new community to itself and to mainstream America. In its dissemination of truisms about Confucian heritages and stereotypes of "model minorities" the literature reveals as much about American ideological desires as it does about "the new Americans."

This paper examines a body of nonfiction children's literature written between 1980 and 200 s that deals with Vietnamese refugees and immigrants who entered the United States from 1975 onwards. The literature is written by non-Vietnamese for a largely non-Vietnamese audience and it creates as well as consolidates notions of the Vietnamese-American not only for a wider American reading public but for the Vietnamese themselves. Although some aspects of this topic have been discussed earlier, the typologies created by and within this body of nonfiction writings have not been analysed in depth and such an analysis reveals strategies of acculturation and containment that have particular resonance in the aftermath of the Vietnam War. ${ }^{1}$

Associate Professor, Department of English, University of Delhi. E-mail: chattarji-s@, yahoo.com.

Research for this paper was conducted at the John W. Kluge Center, Library of Congress, on a Kluge Postdoctoral Fellowship. I would like to thank the staff at the Kluge Center and the Library of Congress.

${ }^{1}$ Earlier studies include Lai Nam Chen, Images of Southeast Asia in Children's Books (Singapore: Singapore University Press, 198 I); Jan Susina, “'Tell Him about Vietnam': VietnameseAmericans in Contemporary American Children's Literature," Children's Literature 
From the fall of Saigon on 30 April 1975 until well into the I99os, large numbers of Vietnamese left or were forced to leave their homeland and arrived in the US either as refugees or as immigrants. Between I97I and I980, they numbered 172,820; between I98I and I990, 280,782; and from I 99 I to 2000,286, I $45 .^{2}$ The Vietnamese influx is divided into three "waves," with the first immediately following the North Vietnamese victory; the second consisting of "boat people," largely ethnic Chinese, fleeing after 1978; and the third comprising reeducation camp survivors and kin of Vietnamese already in the US as well as Amerasian children under the Orderly Departure Program (ODP) (1 979) and the Amerasian Homecoming Act (1987) respectively. James Freeman adds a fourth wave of intermittent asylum seekers between 1983 and 1989 , and a fifth wave which arrived in countries of first asylum after 14 March $1989 .{ }^{3}$ The first-wave arrivals consisted largely of urban, educated, upper-class Vietnamese comprising military personnel as well as bureaucrats and the South Vietnamese intelligentsia. The second wave was more rural-based, comprising fishermen and peasants, along with a large component of ethnic Chinese who had run small businesses in Vietnam. The third wave included survivors of reeducation camps consisting not only of military personnel but of many who had worked for the former South Vietnamese government or had refused to be relocated to the New Economic Zones created by the communist government. These classifications are merely indicative because none of the groups were homogeneous. For example, the first wave included personages such as Nguyen Cao Ky, former prime minister of South Vietnam, along with "Vietnamese air force pilots [who] took their planes, loaded them with friends, family, and often people whom they charged more than \$Io,000 (U.S. currency) per person, and flew them to U.S. bases in Thailand." ${ }^{4}$ The majority of refugees, however, in this first wave

were lower level Vietnamese government officials, teachers, rank and file members of the Vietnamese army and navy, petty traders, farmers and fishermen. They were not necessarily urban, had few skills that were usable in the United States, spoke little

Association Quarterly, I6 (Summer I991), 58-63; Michael Levy, Portrayal of Southeast Asian Refugees in Recent American Children's Books (Lewiston, NY: Edwin Mellen, 2000).

${ }^{2}$ Cited in Joe Ferry, Vietnamese Immigration (Philadelphia: Mason Crest Publishers, 2004), 40.

${ }^{3}$ James M. Freeman, Changing Identities: Vietnamese Americans, 1975-1995 (Boston and London: Allyn and Bacon, I995), chapter 3.

${ }^{4}$ Gail Paradise Kelly, From Vietnam to America: A Chronicle of the Vietnamese Immigration to the United States (Boulder, CO: Westview Press, 1977), 30. 
or no English, and were totally unacquainted with life outside their parishes or villages in Vietnam. ${ }^{5}$

The heterogeneity of the new arrivals and the ways in which the initial cohort was placed in resettlement camps has been analysed in some detail. The literature dwells on surveys of inmates in the four camps at Camp Pendleton, Fort Indian Town Gap, Fort Chaffee and Eglin Air Force Base, and there are more detailed interviews and ethnographic studies of the camp experience and its aftermath. ${ }^{\mathbf{6}}$ Analysts noted differences in vintage attitudes and E. F. Kunz's observation on generic refugee differentiation is applicable to the Vietnamese experience: "Vintage differences may be of great significance. Some vintages are from the outset sympathetic to one another, others may keep more aloof, while again others are outrightly hostile, representing persecutor and persecuted, winners at one time and losers at another."7 Kunz's seminal analysis is borne out by later studies of Vietnamese refugees and immigrants, such as that by Steven J. Gold. Gold noted a type of cohort competitiveness that militates against any homogenizing impetus:

To some recent arrivals, the 1975 cohort was their historical enemy, a corrupt and Westernized urban elite who knew nothing of the rural texture of Vietnamese life. They were described as the sons of colonial administrators who profited from the war and ran before defeat ... Conflicts rooted in ideology, ethnicity, migration experience, background, and subgroup restricted the development of links between these two cohorts of Vietnamese. ${ }^{8}$

5 Ibid., 36.

${ }^{6}$ See Kelly; William T. Liu, Maryanne Lamanna and Alice Murata, Transition to Nowhere: Vietnamese Refugees in America (Nashville and London: Charter House Publishers Inc., 1979); Darrel Montero, Vietnamese Americans: Patterns of Resettlement and Socioeconomic Adaptation in the United States (Boulder, CO: Westview Press, I 979); Paul J. Strand and Woodrow Jones Jr., Indochinese Refugees in America: Problems of Adaptation and Assimilation (Durham, NC: Duke University Press, 1985); David W. Haines, ed., Refugees as Immigrants: Cambodians, Laotians, and Vietnamese in America (Totowa, NJ: Rowman \& Littlefield Publishers, Inc., 1989); Steven J. Gold, Refugee Communities: A Comparative Field Study (Newbury Park, London and New Delhi: Sage Publications, I992); Paul James Rutledge, The Vietnamese Experience in America (Bloomington and Indianapolis: Indiana University Press, 1992); Nazli Kibria, Family Tightrope: The Changing Lives of Vietnamese Americans (Princeton, NJ: Princeton University Press, I993); Freeman; Min Zhou and Carl L. Bankston III, Growing up American: How Vietnamese Children Adapt to Life in the United States (New York: Russell Sage Foundation, 1998); Hien Duc Do, The Vietnamese Americans (Westport, CT and London: Greenwood Press, 1999); Sucheng Chan, The Vietnamese American I.5 Generation: Stories of War, Revolution, Flight, and New Beginnings (Philadelphia: Temple University Press, 2006); Nghia M. Vo, The Vietnamese Boat People, 1954 and 1975-1992 (Jefferson, NC and London: McFarland \& Company, Inc., Publishers, 2006).

7 E. F. Kunz, "The Refugee in Flight: Kinetic Models and Forms of Displacement," International Migration Review, 7, 2 (Summer, 1973), I $25-46$, I $38-39$.

${ }^{8}$ Gold, Refugee Communities, I 2 I, I 27. 
That the Vietnamese experience in the US was further complicated by American involvement in the Vietnam War is noted by Gold and other analysts but elided, erased or justified in much of the children's literature.

The contours of classification for this mixed and alien group of Vietnamese and the depth of research engagement are visible in the body of writings referred to earlier, largely by American anthropologists, demographers, folklorists, psychologists and mental health practitioners, migration studies and refugee experts, oral historians, and the occasional literary scholar who delved into their writings. Thomas A. DuBois outlined some of these interpretative modes in an essay in I993, pointing to how Southeast Asians (Cambodian, Hmong, Laotian and Vietnamese) were objectified as refugees, migrants, immigrants, ethnics or racial minorities. ${ }^{9}$ DuBois's analysis is particularly insightful in the way in which it highlights the creation of a model of the "Southeast Asian as passive" and as an "emblematic victim" in need of professional "caring, counseling, or intervening." 10 As a folklorist DuBois studied adolescent school projects in Philadelphia schools where Southeast Asians were enrolled in significant numbers. While his basic classification offers a useful template for the ways in which various academic and nonacademic discourses made sense of Southeast Asian presences within the United States, DuBois does not deal with the body of children's literature inscribing Vietnamese realities for child and young adult audiences. This literature inscribes some of the typological frames outlined by DuBois but also addresses issues related to exile, identity and belonging, albeit within largely simplified frameworks. The writings contribute to the creation of a Vietnamese-American identity, delineating aspects of "Vietnameseness" for easy comprehension and consumption within American contexts and then morphing into a hyphenated amalgam which represents a new, integrated, and generally hopeful future.

The literature under survey is marked by very high production values. ${ }^{11}$ The books are glossy and well produced, with lots of photographs and graphics providing a positive, uplifting narrative of sometimes painful but ultimately worthwhile journeys from war to peace. Chronologically there is a

9 Thomas A. DuBois, "Constructions Construed: The Representation of Southeast Asian Refugees in Academic, Popular, and Adolescent Discourse," Amerasia Journal, 19, 3 (1993), I-25.

10 Ibid., 4, original emphasis.

11 There are many fictionalized picture book accounts of the Vietnam War and its aftermath which are beyond the ambit of this study. These include Michele Maria Surat, Angel Child, Dragon Child (Milwaukee, WI: Raintree Publishers, 1983); Tran Khan Tuyet, The Little Weaver of Thai-Yen Village (San Francisco: Children's Book Press, 1987); Sherry Garland, The Lotus Seed (San Diego and New York: Voyager Books, 1997); Lawrence McKay, Journey Home (New York: Lee \& Low Books, 1998). 
spread from James Haskins' The New Americans, published in 1980, through to Lori Coleman's Vietnamese in America, published in 2005. Apart from Haskins and Coleman this paper takes into account children's literature by Paul Rutledge (1982), Susan Auerbach (I991), Karen O'Connor (I992), Kenneth Wapner (1995), Keith Greenberg (1997), Tricia Springstubb (2002), C. Ann Fitterer (2003), Lewis K. Parker (2003), Margaret C. Hall (2003), Joe Ferry (2004), and Andrea Warren (2004). ${ }^{12}$ Most of these books are part of a series on new immigrants such as Coming to America (Parker), the In America Series (Rutledge, Coleman), Children in Crisis (Greenberg), Spirit of America (Fitterer), We Are America Series (Hall), In Their Own Voices (Wapner), Finding-Out Books (Haskins), The Changing Face of North America (Ferry), American Voices (Auerbach), Immigrants in America Series (Springstubb), Minorities in Modern America (Rutledge). It is interesting that while some of these authors have knowledge about and sympathy for the Vietnamese, they are all non-Vietnamese who mediate an alien people and their history and culture for a predominantly non-Vietnamese audience. The density of publications, along with the fact that they are not stand-alone texts, is indicative of attempts to place Vietnamese immigrants within a wider matrix of past immigrations which designate the United States as preferred destination and normalize the Vietnamese exodus in terms of those earlier histories of immigration. The specificity of immigrant ethnics is spelt out in individual titles - the Chinese Americans, the Cuban Americans, the Italian Americans, the Russian Americans - but the series designations, along with content, articulate generic tropes of "Americanness" to the portals of which the Vietnamese are the newest entrants.

Most of the books have a basic narrative trajectory beginning with a sketchy history of Vietnam and the war, detailing aspects of the journey to the US, and then focussing on how these Vietnamese became American, a process often emblematized in success stories from the community. There are some variations within this theme and a few which follow generic outlines but offer more complex analyses of the escape-immigration-success story plot, but the persistence of the model across authors and publishing houses is indicative of a discursive formula that circulates with ease and confidence.

In writing new histories, older ones are erased or modified so that the histories of Vietnam and of the war are often conflated, which not only simplifies both histories but also often erases US involvement in the war

12 Levy, Portrayal of Southeast Asian Refugees, discusses aspects of texts by Rutledge, Auerbach, O'Connor, Wapner, and Greenberg. 
and its depredations. In the chapter "The Vietnam War" Lewis Parker writes, "In 1954, Vietnam was separated into two parts - North Vietnam and South Vietnam ... North Vietnam wanted to take over South Vietnam. In 1955 a war started between North Vietnam and South Vietnam."13 While detailed historical exegesis of the complexity surrounding the Vietnam War may be too much to expect in a book for children, the easy causality creates a myth of southern victimization attributable solely to communist intentions and actions. C. Ann Fitterer does mention that the "United States sent soldiers to fight in the Vietnam War,"14 but the focus is on the civil war: "The Vietnam War began in i957. Finally, North Vietnam took control of the government of South Vietnam. The South Vietnamese people were then forced to accept communism." 15 Similarly, Andrea Warren writes, "Both North and South wanted a unified nation, but each wanted its own form of government. Thus began the long war between the two Vietnams, a war that would take many lives and leave no family untouched."16 This focus on the civil war aspect of the Vietnam War is salutary given the extent to which US wartime policies and perceptions, driven by ideological imperatives, overlooked internal divisions within Vietnam and concentrated primarily on the atrocities of the communists or United States forces. As David Chanoff notes, "For the Vietnamese the war was vastly more complex - a maelstrom in which the contending tides of colonialism and liberation, communism and nationalism, reform and revolution, Northern revanchism and Southern regionalism clashed violently and mixed treacherously." 17 The Americans were largely ignorant of these divisions and undercurrents, and created a monolithic rhetoric of saving the South from communism. Truong Nhu Tang, a former member of the National Liberation Front (NLF) and minister in the Provisional Revolutionary Government of South Vietnam, commented on the American inability to perceive political nuances:

The Eisenhower and Kennedy administrations had chosen to regard Ho Chi Minh as a tool of Chinese expansionism, ignoring the separate integrity and strength of Vietnamese national aspirations. Just so, the Johnson and Nixon administrations

${ }^{13}$ Lewis K. Parker, Why Vietnamese Immigrants Came to America (New York: Rosen Publishing Group, Inc., 2003), 4-5.

${ }^{14}$ C. Ann Fitterer, Vietnamese Americans (Chanhassen, MN: The Child's World, 2003), I 3.

15 Ibid., 7 .

16 Andrea Warren, Escape from Saigon: How a Vietnam War Orphan Became an American Boy (New York: Melanie Kroupa Books, Farrar, Straus and Giroux, 2004), xvii.

17 David Chanoff and Doan Van Toai, "Vietnam" A Portrait of Its People at War (London and New York: I. B. Tauris, 1996), xxi. 
persisted in treating the NLF as part of a North Vietnamese monolith, casually shrugging aside the complex realities of the Vietnamese political world. ${ }^{\mathbf{1 8}}$

In the narratives of Parker, Fitterer and Warren the focus is on internal divisions, but those are then essentialized to create a picture of the war in which the Vietnamese were primary combatants, and although the "United States sent soldiers to fight in the Vietnam War" its role is either ambiguous or, in many instances, absent. Within this juvenile historical framework Vietnamese, particularly communist, agency, indeed malevolence, is highlighted and this focus is instrumental in the creation of a victimized Southern Vietnamese identity, and the disappearance of the US altogether. In this postwar scenario the elision of American involvement, violence and occasional atrocity serves to reorient rhetorically and conceptually the imagined spaces of America as a beacon of hope and solace untroubled by violent interventions and histories. For many Vietnamese refugees America was indeed a welcome abode after the terrors of pirates or the horrors of reeducation camps, but the sense of arrival was not untroubled by memory or contradictions. As Andrew Lam, a Vietnamese-American journalist, writes, "To grow up Vietnamese in America, after all, is to grow up with the legacy of belonging to the loser's side and to endure all that [it] entails. "19 It is interesting, however, that Viet Kieu (the Vietnamese term for immigrants in the US) generally do not mention these pasts or the destruction of their beloved South Vietnam by their allies, the Americans. ${ }^{20}$ Thus the nostalgic construction of a lost homeland erases unpleasant and inconvenient histories.

Oral histories of the Vietnamese-Americans, such as James M. Freeman's Hearts of Sorrow, further the cause of historical rewriting. Despite including people from various backgrounds in his interviews, there is a remarkable conformity of central ideas: all hate communism (for political, personal or unspecified reasons), all are nostalgic about the country they left behind, none analyse in any detail why the communists won, all see the "liberation" as a sham, and some hope to return to a free, noncommunist Vietnam. There

18 Truong Nhu Tang, Journal of a Vietcong (London: Jonathan Cape, I 986), 2 I 3.

19 Andrew Lam, "Love, Money, Prison, Sin, Revenge," in De Tran, Andrew Lam and Hai Dai Nguyen, eds., Once Upon a Dream ... the Vietnamese-American Experience (Kansas City, MO: Andrews and McMeel, I995), 83.

20 There are some exceptions in children's writings which do mention American involvement (Tran Khan Tuyet) and discuss the war (Huynh Quang Nhuong's The Land I Lost: Adventures of a Boy in Vietnam (1982) and Water Buffalo Days (1997)), but they too seem to participate in nostalgic reconstructions of the homeland. This may be unsurprising given the exigencies of exile but important within the context of writing, rewriting and remembrance. 
are no nuanced or disillusioned communist accounts (such as the ones narrated by Duong Thu Huong and Le Minh Khue ${ }^{21}$ ) and only one narrator refers to anticommunist feelings amongst Vietnamese immigrants. It is also significant that America's role in the war becomes a nonevent and has no consequences for Vietnam insofar as the communists are the cause of all problems. The very real and harrowing tales told by Freeman's narrators - of reeducation camp, of escape, of settling in the US - are ideologically tweaked to suit dominant US narratives of a war undertaken for noble ends. ${ }^{22}$ Juvenile histories participate in that rewriting reconfiguring the Vietnam War to create paradigms of hope and solace for the losers in the aftermath of a purely internal and Vietnamese squabble.

Don C. Locke's serious and sympathetic analysis of Vietnamese communities within a multicultural frame plays down the US role in the Vietnam War as well as its impact on poverty and deprivation in the South prior to the communist victory. Locke portrays the period of the late ig6os (when US troops were in Vietnam in force) as a period of relative stability, but this period

was short because the National Liberation Front continued to battle in the cities and towns while the United States began withdrawal of troops and aid ... The South Vietnamese people were trapped. The protecting U.S. military had deserted them, their rural economy had collapsed, and their leaders had been jailed or sent to camps. ${ }^{23}$

The United States is portrayed as a benign and paternalistic protector whose sudden withdrawal creates the conditions for South Vietnamese misery. To some extent this was true because without US support the weak South Vietnamese government could not stand up to the more disciplined communist armies and the communist victory opened the door to subsequent terrors for many in the South. However, this narrative elision ignores US military actions in Free Fire Zones or the use of Agent Orange or its support for the Strategic Hamlet Program, all of which contributed to the collapse of the rural economy in the South, the creation of slums in Saigon, and the impoverishment of vast numbers of people. Locke's representation

${ }^{21}$ See, for example, Duong Thu Huong, Paradise of the Blind, trans. Phan Huy Duong and Nina McPherson (New York: William Morrow and Company, Inc., I 988); Le Minh Khue, The Stars, the Earth, the River, trans. Bac Hoai Tran and Dana Sachs, ed. Wayne Karlin (Willimantic, CT: Curbstone Press, I997).

${ }^{22}$ See James M. Freeman, Hearts of Sorrow: Vietnamese-American Lives (Stanford, CA: Stanford University Press, 1989).

${ }^{23}$ Don C. Locke, Increasing Multicultural Understanding: A Comprehensive Model (Thousand Oaks, London and New Delhi: Sage Publications, 1998), I 34. 
of "multicultural" perspectives weaves anticommunist points of view into the historical narrative, so that sympathy for a suffering people comes at the cost of historical accuracy.

While some juvenile narratives dwell on the journey and the difficulties involved, most see it as a passage to a better existence. Parker states this transition as an undeniable fact: "After the war, over 200,000 people left Vietnam to find a better life." 24 Coleman writes, "They fled during and after a terrible civil war that tore apart their homeland. "25 Once again the civil war emphasis serves to minimize, if not erase, the fact of US military presence. James Haskins is aware of the often tedious progression from the status of boat person to that of US immigrant, but he sees this wait (in resettlement camps which could be overcrowded, unsanitary and violent, as in Pulau Bidong in Malaysia) as time well spent: "The process would be slow, but in a couple of years all those Boat People that no other country would have would be taken into the United States, the only country in the world with a statue of liberty in one of its major harbors. "26 Many refugees in countries of first asylum such as Hong Kong, Indonesia, Malaysia and Thailand spent more than a couple of years waiting for their applications to be processed. While the United States accepted the largest number of refugees, countries such as Canada welcomed Vietnamese boat people as well. Given the sometimes visceral opposition in many countries to US policies during the Vietnam War it was not entirely surprising that these countries perceived it the primary responsibility of the United States to rehabilitate the victims of a long and vicious war. Indeed the idea of national responsibility was an argument accepted by some within the United States, especially when the refugee influx could be construed as that of ordinary people "voting with their feet" against communism. ${ }^{27}$ The ideological calculations of the Cold War which had led the United States to the war in Vietnam continued to shape policy prescriptions and perceptions in the aftermath of the lost war. As Paul Strand and Woodrow Jones observe,

The close association between the U.S. government and the defeated South Vietnamese government, as well as the humanitarian and international political considerations, shaped initial federal actions in support of Indochinese evacuation

${ }^{24}$ Parker, Why Vietnamese Immigrants Came to America, io.

${ }^{25}$ Lori Coleman, Vietnamese in America (Minneapolis, MN: Lerner Publications Company, 2005), 5 .

${ }^{26}$ James Haskins, The New Americans: Vietnamese Boat People (Hillside, NJ: Enslow Publishers, I980), 44 .

${ }^{27}$ Susan Auerbach, Vietnamese Americans (Vero Beach, FL: Rourke Corporation, Inc., I99I), 39. 
and resettlement ... Indochinese refugees who came to the United States did not need proof of persecution. The definition of a refugee included anyone who left a Communist country. ${ }^{28}$

The politics of the Cold War and its influence on US refugee policy is clear if one looks, for example, at differences between the processing of Vietnamese and Chileans during the I970s. In "I975 the United States gave 80,000 Vietnamese the security clearance required for refugee status in only 3 months. In contrast, 2 years after I 2,000 persons fled Chile's rightist coup, only 26 had been cleared to live in the States. "29

Despite dominant ideological considerations, polls and interviews amongst Americans (particularly in the South, which had been more supportive of the war) showed a distinct lack of enthusiasm for the new settlers. A Gallup poll in early May i975 showed that "fifty-four percent of all Americans (were) opposed to admitting Vietnamese refugees to live in the United States and only thirty-six percent (were) in favour."30 Newsweek quoted an Arkansas woman: "They say it's a lot colder here than in Vietnam. With a little luck, maybe all those Vietnamese will take pneumonia and die." 31 These negative reactions can be attributed not only to individual predilections but also to the ways in which "the refugee serves as a reminder of the war and our involvement and responsibility in the face of a predominant mood in the country to forget and obliterate the memory of this unsuccessful effort." ${ }^{32}$ It was one thing to fight for an anti-communist ally in a distant part of the world and quite another when that defeated ally became one's neighbour and cost federal dollars in the midst of an economic downturn. America's collective attempt to forget the war was considerably complicated by the Vietnamese influx, and while Hollywood set about rewriting the conflict from a US point of view, the body of children's writings revalidates central myths of America as refuge and multicultural haven by eliding US involvement in the war and emphasizing a narrative of hope. Andrea Warren, describing a Vietnamese orphan being airlifted as part of Operation Babylift, writes, "He was leaving a land of war and heading to a land of promise and peace." ${ }^{33}$ The generic difference essentializes Vietnam

${ }^{28}$ Strand and Jones, Indochinese Refugees in America, I4I, I42. Prior to the Vietnam War, "the first Refugee Relief Act (RRA), which became law in 1953 , and its amendments, allowed for the admission of people persecuted by communist governments." Ferry, Vietnamese Immigration, 50.

30 Cited in Time, i9 May 1975, 9.

${ }^{32}$ Liu, Lamanna and Murata, Transition to Nowhere, 70.

33 Warren, Escape from Saigon, 59. Warren's views may be contrasted with those of Zigler, who referred to the "massive disrespect for the Vietnamese people (both North and South)" implied in Operation Babylift, which suggested that the Vietnamese would not care for 
as "a land of war" while configuring the Americans as rescuers and saviours rather than as effective contributors to the war. ${ }^{34}$ Warren's before-and-after division emphasizes a teleological progression where arrival in the United States is clearly a moment of present and future celebration. The actual and ideological journey from Vietnam to America was fraught in many ways and most children's literature flattens complexities to create a disjunction between two nations, cultures and lives in order to emphasize the successful Americanization of these new peoples.

The process of becoming American is conceived in different ways. For Greenberg the acquisition of US citizenship is an epiphanic moment encapsulating a clean break from the past: "During their official ceremonies, parents and children stood together, glowing, as they raised their arms to take an oath of allegiance to their new country. Finally, it seemed, the bad times seemed behind them. And the future was full of promise." 35 Unlike many other immigrant groups in the US, a large number of Vietnamese came as refugees and, like all refugees, they were dispossessed not only of material things but also of "a personal and social heritage that can never be recaptured". 36 This sense of dispossession and despair haunts VietnameseAmerican writings as the unification of Vietnam under the communists heralded the extinction of the country many South Vietnamese called home. Unlike Greenberg's narrative, assimilation into America as citizens is a moment both of triumph and of loss. As a father tells his daughter who wants to change her Vietnamese name to "Angie" in Quynh-Trang Cindy Nguyen's short story "Byline," "When Saigon fell in I 975, we lost our country. Now we're becoming U.S. citizens, so we're losing our nationality ... Can't we at least keep our names?"37 In this context names become a significant and perhaps the only marker of difference, identity and ethnic coherence, and the future of promise outlined by Greenberg is neither linear nor altogether welcoming. ${ }^{38}$

their children and that "being raised by Americans in America was superior to being raised Vietnamese in Vietnam." Cited in Liu, Lamanna and Murata, 72.

34 Tran Khan Tuyet's The Little Weaver of Thai-Yen Village does not erase American involvement but it too participates in the narrative of hope.

${ }^{35}$ Keith Greenberg, Vietnam: The Boat People Search for a Home (Woodbridge, CT: Blackbirch Press, Inc., I 997), 3 I.

${ }^{36}$ Bruce Grant, Boat People: An "Age" Investigation (Harmondsworth: Penguin Books Ltd., I 979), 6.

37 Quynh-Trang Cindy Nguyen, "Byline," in Huynh Sanh Thong, Hoang Ngoc Hien and Truong Vu, eds., Vietnam Review, 2 (Spring--Summer, I 997), 447.

38 Nazli Kibria, in her work on Vietnamese families in Philadelphia, noted, "The Vietnamese immigrants recounted feelings of euphoria in the days immediately following arrival in the United States. There was excitement at being in a country that carried images of great 
Fitterer acknowledges difficulties faced by the Vietnamese but postulates cultural traits and affinities that help to bind the new arrivals to their adopted country. "Moving to the United States was - and continues to be - filled with difficult struggles for Vietnamese Americans. But their courage, hard work, family values, and commitment to education have helped them find ways to be successful in a culture very different from their homeland." 39 "Hard work, family values," respect for elders, "morality and ethics" were some of the attributes that were ascribed to Confucianism and its influence on Vietnamese culture. "For these groups [Chinese, Japanese, Koreans, Vietnamese], the home culture emphasizes education as a means to mobility. It values consensus, respect, discipline, hard work, the centrality of the family, and social harmony." ${ }^{40}$ Min Zhou and Carl Bankston offer analytical insights into community formation and the challenges of growing up American in Versailles Village, New Orleans, but they repeat clichés of Confucian values transplanted onto American landscapes which are only partially true. In effect the narrative of success and integration that Fitterer and more serious analysts lay out leads to the "model-minority" appellation and syndrome. This is a positive stereotype of Asian Americans as high achievers and may help "Vietnamese students in their adaptation to school." " The "model-minority" tag was swiftly adopted by the popular press, repeated in children's and other literature on the VietnameseAmericans, and internalized by the community because it provided a point of successful entry into mainstream society through educational prowess. ${ }^{42}$ However, as Zhou and Bankston and Hien Duc Do, among a host of analysts, observe, many Vietnamese-Americans who buy into the modelminority myth do not comprehend the troubles their children go through in school. Part of the pressure of assimilation from within the VietnameseAmerican community is reflected in the growth of juvenile delinquency, gangs and general disaffection among Vietnamese kids who do not fit the

material wealth and personal freedom ... But this initial elation soon dwindled. It was replaced by often overwhelming anxieties about the task of building a new life and of regaining the middle-class status that had been lost in the years following 1975." Kibria, Family Tightrope, 73.

40 Zhou and Bankston, Growing up American, I 43.

${ }^{39}$ Fitterer, Vietnamese Americans, 27.

42 "The model minority is an identity that is testimony to the Asian American ability to be good citizen, productive worker, reliable consumer, and member of a niche lifestyle suitable for capitalist exploitation. The model minority is the vehicle of entry for a racial population not only into American capitalism but also into American politics - indeed, the two go hand in hand." Viet Thanh Nguyen, Race \& Resistance: Literature \& Politics in Asian America (Oxford and New York: Oxford University Press, 2002), Io. 
model-minority frame and the trajectory of success that Americanization implies. ${ }^{43}$

Within children's literature there are occasionally more complex and sensitive insights into the process of Americanization. Thus Margaret Hall writes,

In the past, some groups of immigrants worked so hard to fit in as Americans that many of their traditions were lost. Most Vietnamese immigrants tried to hold on to their language and traditions. This sometimes made it hard for old and young Vietnamese Americans to understand one another. ${ }^{44}$

While primarily a primer on the benefits of immigrating to the US, Hall's narrative is sensitive to the problems and pressures of assimilation, as well as to the double bind of acculturation into dominant American cultural modes. Similarly, Susan Auerbach's Vietnamese Americans, written for a young adult audience, refers to resettlement problems faced by the Vietnamese and goes on to define a "Vietnam syndrome" from their perspective:

Many Vietnamese Americans suffer from a 'Vietnam syndrome' quite different from that of American veterans. They feel betrayed by both the South Vietnamese and American governments for failing to stop the Communist takeover of their country, and they are angry with recent books and movies in the United States which portray the Vietnamese in minor roles as victims of the war. ${ }^{45}$

Auerbach unpacks the easy hybridity articulated by most children's literature whereby the Vietnamese are transformed into Vietnamese-Americans through osmotic immersion and desire. The success narratives are emblematic of this process of having "made it" in America and they elide, as argued earlier, complex struggles and compromises.

These erasures raise a set of fundamental questions: who is an American, at what point do Vietnamese refugees become Vietnamese-Americans, and in what ways are these "new Americans" distinctive from their hyphenated fellow Americans? That children's literature tackles these questions, directly or by implication, may seem surprising given the ideological weight and instrumentality of the questions, but what is equally significant is the answers outlined by the writings because these answers both determine the ideological domains within which the literature functions and set the boundaries

${ }^{43}$ See Hien Duc Do, The Vietnamese Americans, chapter 3. Also Zhou and Bankston for the ways in which the model-minority tag is used to berate other minority groups, particularly African Americans. "One of the reasons the model minority concept is so unfair is that it compares groups of peoples with entirely dissimilar backgrounds." Zhou and Bankston, 238.

44 Margaret C. Hall, Vietnamese Americans (Chicago: Heinemann Library, 2003), 24.

45 Auerbach, Vietnamese Americans, 73. 
that define "the new Americans" to the Vietnamese and to a wider American public.

James Haskins's first chapter is titled "Who Is an American?" and he answers the question by referring to specific Vietnamese who are representative of the generic group.

They [My Lan Huynh, Le Tien Hung, Loc Le] are Americans because they are here and they want to be here. They are Americans because they want to learn English and go to McDonald's and get jobs so they can buy The Jacksons records and color TV. Most of all, they are Americans because they believe that it is a land where people can live in freedom, can work hard and enjoy what they have worked for, can go to any church they want to, and can have a say in who their leaders are. Believing in America - that's what makes them Americans. ${ }^{46}$

Haskins echoes the question raised by Hector St. John de Crèvecoeur in the eighteenth century, laying out a similar contrast between an indifferent past and an optimistic present. Crèvecoeur implied that the American is special because he is not subject to the constraints of his European forebears; the American has unique opportunities to make his own life anew, to refashion himself as if there were no past; in America history begins. ${ }^{47}$ American self-fashioning is an integral part of the national imaginary and Haskins envelopes the Vietnamese within this continuing narrative. ${ }^{48}$ While "freedom" is signposted as the locus of desire and achievement-both secular and religious - it is interesting that Haskins's late twentieth-century take on Crèvecoeur is rooted in consumerism and the English language. The historical, continental, ethnic and linguistic differences between Crèvecoeur's and Haskins's "new Americans" are bridged by new versions of the Protestant work ethic, best embodied in the kitsch Confucianism attributed to the Vietnamese. Thus becoming American is inextricably tied to being conversant with a techno-consumer world which is quintessentially American: "Learning a whole new language was hard enough. Learning a whole new way of life must have seemed almost impossible" $" 49$ - a whole

46 Haskins, The New Americans, 4.

47 "He is an American, who, leaving behind him all his ancient prejudices and manners, receives new ones from the new mode of life he has embraced, the new government he obeys, and the new rank he holds ... Here individuals of all nations are melted into a new race of men, whose labours and posterity will one day cause great changes in the world ... There is room for everybody in America." Hector St. John de Crèvecoeur, "Letter III: What Is an American?", in idem, Letters from an American Farmer (London: J. M. Dent \& Sons Ltd., I95 I ; first published I782), 45, 57 .

${ }^{48}$ F. Scott Fitzgerald's The Great Gatsby is perhaps the best known representation and critique of this myth of self-renewal.

${ }^{49}$ Haskins, 5 $\mathrm{I}$. The catalogue is from an earlier paragraph in Haskins. 
new way of life consisting of refrigerators, hairsprays, Scotch tape dispensers, light bulbs, TV, radios, record players, toothpaste, bar soap, flush toilets, cars and so on. Consumer fetishism and the equation of material objects with successful adaptation to a new society were internalized by many Vietnamese immigrants. Steven Gold writes of a Vietnamese couple, the Trans, who stand out at a community wedding "because of their high degree of assimilation. Attired in impeccable business suits, driving a new Honda, and professionally employed in Silicon Valley, their way of life had more in common with that of middle-class Americans than their recently arrived relatives."50 Gold analyses disparities within Vietnamese American communities to highlight the limitations of this assimilation model and the ways in which this exacerbates cohort competitiveness. Even within children's literature Margaret Hall quotes a recent immigrant who articulates a more complex response: "Just because we have a comfortable life in America, we'll not forget our country." immersion in its networks of labour, production and consumption - the immediate basis and primary challenge for a majority of Vietnamese - but coming to terms with dualities of heritage, culture and memory. ${ }^{\mathbf{5 2}}$ Within the consumption and "model-minority" paradigm championed by most children's literature and mainstream media, Vietnamese refugees are transformed into Vietnamese-Americans at two points in their redemptive journey: when they leave the refugee camps and when they acquire middleclass status. ${ }^{\mathbf{5 3}}$ This seemingly seamless transition is disrupted at various levels, and Tricia Springstubb's The Vietnamese Americans is one example of a text for young adults which expresses some of the problems that make the acquisition of Americanness a little trickier than figuring out how to use toothpaste or flush toilets.

Amongst all the children's literature surveyed, Springstubb alone ascribes the post-I975 poverty of Vietnam to the war rather than solely to communist malevolence. "The communists inherited a devastated, divided nation. Much of the land, ravaged by bombing and chemical warfare, could not be farmed. The country's infrastructure was all but destroyed, making transport of food

50 Gold, Refugee Communities, ro8.

51 Hall, 27.

52 There are picture books specifically centred on Vietnamese-American children who go home for a visit or who wish they could go home. See McKay, Journey Home; and Jeremy Schmidt, Two Lands, One Heart: An American Boy's Journey to His Mother's Vietnam (New York: Walker, i 995).

53 As a matter of policy Vietnamese refugees in stateside camps were dispersed to all states of the union so as not to be a burden on any particular part of the country. Such dispersal, it was premised, would lead to a "disappearance" of the refugees until, of course, they emerged as successful Vietnamese-Americans. 
and goods difficult." ${ }^{54}$ Of course the Communist Party's incompetence, corruption and vengeful attitude towards their southern countrymen did not help matters, but Springstubb retrieves some of the consequences of US involvement which are often lost in the narratives of gratitude and redemption. She then dwells on survivor guilt, poverty, the existence of gangs, the "bittersweet" pain of exile and adaptation, and the ways in which the restoration of US-Vietnam diplomatic ties (in 1995) reestablished memorial bonds.

Although it is more than a quarter of a century since the first Vietnamese fled, the older immigrants have never forgotten the pain of leaving against their will. Despite their children's many successes, the pain remains part of their legacy. The chance to freely reconnect with their first country is deeply comforting. ${ }^{55}$

Unlike many immigrants who make conscious decisions to leave their mother country for another - often for economic betterment - the first wave of Vietnamese refugees as well as a majority of the "boat people" left out of fear of persecution by the communists or were forced to leave, as in the case of the ethnic Chinese. The often abrupt wrench from one's homeland was compounded in many instances by piracy, rape, long interims in refugee camps and the sundering of families. While it is true that Vietnamese invested in the education of their children as a mode of working their way into American mainstream respectability, that patina of success barely concealed the grief and alienation of the older generation. Crèvecoeur and Haskins, in their different contexts, perceive the "new American" as constitutive of a process that culminates with arrival, success and assimilation in the new land. It is a prescriptive teleology that obscures if not obliterates the pasts from which the freshly minted American has arrived, and this partially explains why US participation in the Vietnam War is so skilfully curtailed or curtained off in most juvenile (and many mainstream) narrations. Within the Crèvecoeur-Haskins paradigm there is little space for painful memories, alienation, nostalgia or a desire to reinstate contact with the "first country," because that would imply a continuum, a complex set of negotiations between presents and pasts, rather than the finality articulated in the "Believing in America - that's what makes them Americans" tautology. The only pasts that can exist in such ideologically sequestered spaces are stereotypes or unmediated nostalgia, and politically correct but banal homage to a seemingly static Confucianism that guides the Vietnamese towards the 54 Tricia Springstubb, The Vietnamese Americans (San Diego, CA: Lucent Books,
2002), 29. 
goal of being better Americans. ${ }^{\mathbf{5 6}}$ "Vietnam is an ancient land, both beautiful and mysterious" $" 57$ is a classic orientalist strategy for containing and erasing pasts which cease to be of interest once the Vietnamese "other" is transformed into the Vietnamese-American subject.

Vietnamese-American subjectivity is constructed within the cusp of immutable but essentially portable (if not dispensable) cultural artefacts such as the celebration of Tet Mau Than, the establishment of ethnic enclaves such as Little Saigon in Orange County, California or Eden Center in Falls Church, Virginia, and the dissemination of ethnic food within and outside these enclaves. These festivals and foods flag Vietnamese-American distinctiveness within a mosaic of competing cultures and they provide a sense of coherence and community to the ethnic cohorts who participate in these productions. ${ }^{58}$ At another level, because distinctions are predicated on easily discernible and relatively superficial markers, they tend to create stereotypes which exoticize the Vietnamese, thereby rendering complex culture-specific events such as Tet into cultural products for consumption by mainstream America. ${ }^{59}$ The dissemination of hyphenated Vietnameseness is available in children's literature as well as in media representations. Springstubb cites an article in Asian Week which "reported that many Vietnamese living in southern California's Little Saigon feel the news media focuses too much on their food, festivals, and crime. Leaders complained that the news perpetrated stereotypes, that of the hardworking 'nerdy' student, for example. "60 While there is a self-reflexivity in community leaders' awareness of the circulation of stereotypes, those very leaders subscribe to certain generic notions of Vietnamese "tradition" and are self-appointed defenders

${ }^{56}$ Haskins writes, "They [the boat people] may have hated the government, but the country was their home and there are things they miss about it, like the way the sun rose over the mountains, or the way the fields looked just after the monsoon season was over." Haskins, 54. This is more reflective in its awareness of loss but does not distract from the surge towards a new and better life.

57 Warren, Escape from Saigon, xvii.

58 "An ethnic enclave can serve various functions for its members such as sharing of information on how to cope with the new culture, providing a somewhat familiar social life, and protecting the refugee or immigrant from cultural shock. Under certain situations, an ethnic subculture can also preserve tradition and cultural continuity." Alden E. Roberts and Paul D. Starr, "Differential Reference Group Assimilation among Vietnamese Refugees," in Haines, Refugees as Immigrants, 43.

59 "There are many aspects of culture that never become symbols of ethnic identity despite the fact that they may be central or crucial to a community's daily life. In fact, the litany of 'acceptable' symbols or tropes of ethnicity in American culture: e.g., foodways, festivals, handicrafts - reflect a power structure that prescribes certain acceptable modes of difference within the society and castigates others." DuBois, "Constructions Construed," I 3.

${ }^{60}$ Springstubb, 95 . 
of stereotypical ideations of Vietnameseness. ${ }^{61}$ Apart from crime, children's literature stresses precisely the attributes cited by Springstubb and because they are written for children and young adults they help to nurture stereotypes, freeze-framing them for the future.

Becoming American is, as innumerable studies testify, a fraught and complex process defying the comfortable linearity outlined in most children's literature. “After the war, over 200,000 people left Vietnam to find a better life." Lewis Parker's before-after story charts the dominant strain of difficult but worthwhile escape towards a comfortable, comforting future. Don C. Locke highlights a more ambiguous transit:

Refugees often have a kind of love-hate relationship with their new country. They may be grateful to the new country for their freedom and the prosperity they can potentially have there, but they are often unable to accept the new country fully because it cannot provide all the things the refugees lost when they were forced to leave their homeland. ${ }^{62}$

Locke's insight is accurate, although he does not delve into the specificities of Vietnamese contexts, especially the war which the South lost and which scarred the generation that lived through that loss and subsequent displacement. That becoming American cannot be charted in terms of absolute departures from the past is evident in many immigrant testimonies and analyses.

It is thus not an "either-or" situation for the refugees, a choice between their "traditions" and American "modernity." Rather, we suggest that refugees can (and do) maintain "their proper normative stance" at the same time as they are coming to grips with American life. This bodes well both for refugee achievement and for the maintenance of cultural diversity in the United States. ${ }^{63}$

This upbeat analysis obfuscates the painful negotiations necessitated not by equable relations between "normative" traditions and "American life" but by profoundly unstable and destabilizing relations that threaten the equanimity desired by dominant multicultural discourse and indeed the immigrant. In some instances the evocation of Vietnamese "tradition" served to foreground the undesirable and disruptive aspects of becoming American. "Many adults [in Versailles Village, New Orleans] feared that Americanization would undermine the ethnic identity of their youths. In their

61 "Aware of the transformation that has occurred in their home countries, some refugees believe that they are the sole repository of their traditional culture." Gold, Refugee Communities, i 8.

${ }^{62}$ Locke, Increasing Multicultural Understanding, I 32.

${ }^{63}$ John K. Whitmore, Marcella Trautmann and Nathan Caplan, "The Socio-cultural Basis for the Economic and Educational Success of Southeast Asian Refugees (1978-1982 Arrivals)," in Haines, I 37. 
words, 'Our Vietnamese culture is of steel, but yours [American culture] is acid that dissolves the steel." "64 The love-hate relationship between refugee/ immigrant and the benefactor country takes on an adversarial tone which posits cultural hierarchies wherein the "superior" Vietnamese traditions are corroded by the "superficial" American ones. The sentiment expresses matrices of desire, anxiety, hate, impotence, insecurity and pride which coalesce in daily interactions with the "acid" of American culture into which the new generation of Vietnamese are enculturated. Given the complexities involved it is perhaps not surprising that children's literature, even that addressed to young adults and more acute in its observations of Vietnamese-Americans, tends to articulate a clean and wholesome narrative of transformation and belonging. Thus Parker enumerates twenty-five years of Vietnamese American successes: "Many have started their own businesses such as restaurants and jewelry shops. Others have become lawyers, doctors, teachers and scientists." The facing-page photograph caption reinforces the success text: "Tuan Vo-Dinh is a Vietnamese immigrant who became a successful scientist. He invented an important machine for testing blood. " provides an overview: "The Vietnamese Americans have become a strong and thriving community in the United States."

While celebrating Vietnamese-American success the narratives of escape and hope enumerated in most juvenile works tend to write out traumas and anxieties, creating discursive spaces where grit and determination triumph over adversity upon arrival in the US. Similar discursive hegemony operated in different contexts during the war, where the "facelessness of the enemy and their lack of voice - as well as the lack of voice of America's South Vietnamese allies - created a void for American discourse to dominate." ${ }^{\mathbf{6 7}}$ In the war's aftermath, Americans constructed their involvement in terms of victimhood - of the war itself, an unresponsive Congress, an unpatriotic antiwar movement, the media. ${ }^{68}$ The Vietnamese were erased from these

${ }^{64}$ Cited in Zhou and Bankston, Growing up American, 2 I 4.

${ }_{65}$ Parker, Why Vietnamese Immigrants Came to America, i 8-1 9.

${ }^{66}$ Coleman, Vietnamese in America, 49. Coleman and Rutledge append a list of "notable Vietnamese Americans" to bolster the success narrative.

${ }^{67}$ Nguyen, Race \& Resistance, I I I. Discourse dominance is evident in Hollywood representations of the Vietnam War, ranging from The Green Berets to The Deer Hunter to Platoon.

${ }^{68}$ There is a distinguished literature which analyses the outlines and implications of the United States as victim during and after the Vietnam War. H. Bruce Franklin, Vietnam \& Other American Fantasies (Amherst: University of Massachusetts Press, 2000); and Katherine Kinney, Friendly Fire: American Images of the Vietnam War (Oxford: Oxford University Press, 2000), are two notable examples. 
victim narratives. With their arrival in the US Vietnamese voices were recovered, but within contexts of victimization and ultimate success in collaborative autobiographies such as Le Ly Hayslip's When Heaven and Earth Changed Places or in children's literature. In the latter the Vietnamese are seen primarily as victims of communism and this helps to erase the US and South Vietnamese role in the war. The success narratives recuperate Vietnamese voices within contexts that disinter responsibility and agency except when they relate to escape and to becoming American, which is the culminating point of arrival and becoming. The "Vietnam" retrieved in the VietnameseAmerican is a matrix of nostalgia, packaged social and cultural myths, and clichéd "traditions" which are then melded with middle-class hard work and success to create a "new American." There are more complex narratives within the interstices of a model-minority paradigm, but children's literature is largely monochromatic and satisfied in its representations of yet another successful fit within the larger ethnic mosaic of the United States. This is not surprising given the editorial and narrative need to present tales of travel, immersion and success in linear fashion for young audiences. What is remarkable, however, is the extent of ideological and discursive cohesion, the insidious writing of "other" voices to create a dominant field within which the "new Americans" are placed and defined, a type of ventriloquism that is profoundly disabling even though it is packaged seductively. Recent writings by Vietnamese Americans recuperate agency and voice but they do not do so in a vacuum. The body of children's literature mentioned here is prominent in the wider market but largely absent in academic analysis. The retrieval of nonfiction children's literature helps to focus on how typologies of the Vietnamese-American are created within a genre and how that impacts on the community's representations of itself as well as on mainstream ideological desires. 